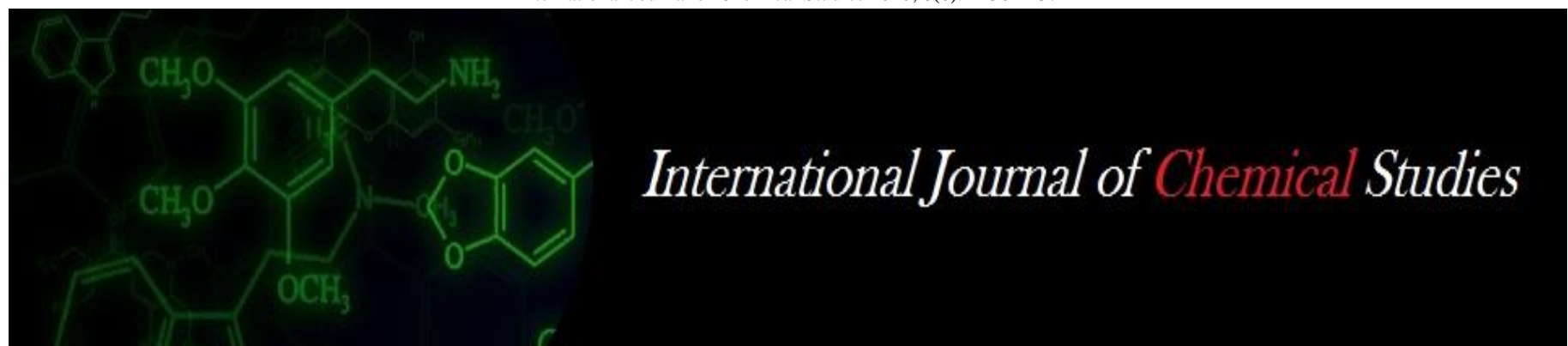

P-ISSN: 2349-8528

E-ISSN: 2321-4902

www.chemijournal.com

IJCS 2020; 8(6): 2156-2157

(C) 2020 IJCS

Received: 15-09-2020

Accepted: 28-10-2020

\section{Panchal RK}

Ph.D. Scholar, Dept. of Fruit

Science, ASPEE College of

Horticulture and Forestry,

Navsari Agricultural University,

Navsari, Gujarat, India

\section{Patil SJ}

Research Scientist

(Horticulture), Agriculture

Experimental Station, Navsari

Agricultural University, Paria,

Gujarat, India

\section{Chawla SL}

Associate Professor, Dept. of

Floriculture and Landscape

Architecture, ASPEE College of

Horticulture and Forestry,

Navsari Agricultural University,

Navsari, Gujarat, India

Corresponding Author:

\section{Panchal RK}

Ph.D. Scholar, Dept. of Fruit

Science, ASPEE College of

Horticulture and Forestry,

Navsari Agricultural University,

Navsari, Gujarat, India

\section{Yield and yield attributes of banana (Musa paradisiaca L.) cv. Grand Nain influence by foliar application of silicon}

\section{Panchal RK, Patil SJ and Chawla SL}

DOI: https://doi.org/10.22271/chemi.2020.v8.i6ae.11091

\begin{abstract}
The present experiment was conducted at Regional Horticultural Research Station, ASPEE College of Horticulture and Forestry, Navsari Agricultural University, Navsari during 2017-18 and 2018-19. An experiment was laid out in a randomized block design, comprising of three levels of potassium silicate and silicic acid (1, 2 and $3 \mathrm{ml} / \mathrm{l} / \mathrm{plant})$ along with control. The treatments were replicated thrice. The effects of foliar applications at $2^{\text {nd }}, 3^{\text {rd }}$ and $4^{\text {th }}$ months after planting of different levels of potassium silicate and silicic acid on yield and yield attributes of banana cv. Grand Nain were recorded. The results indicated that foliar application of potassium silicate @ $3 \mathrm{ml} / 1 / \mathrm{plant}$ at $2^{\text {nd }}, 3^{\text {rd }}$ and $4^{\text {th }}$ MAP recorded significantly the maximum length and girth of bunch, weight of bunch, number of hands per bunch, fingers per bunch, weight of $3^{\text {rd }}$ hand, length of finger and finger weight from $3^{\text {rd }}$ hand and fruit yield.
\end{abstract}

Keywords: Potassium silicate, silicic acid, yield and yield attributes

\section{Introduction}

Banana is a heavy feeder of nutrients and thus need balanced nutrition for optimum growth and fruit production and in turn potential yields. A deficiency or excess of nutrients can cause substantial damage to the plant. Studies have clearly demonstrated that for high productivity of banana, application of recommended dose of essential nutrients at appropriate growth stage is necessary (Thangaselvabai et al., 2009) ${ }^{[9]}$. Further the crop well responds to micronutrient and some of the beneficial element like silicon. Silicon is not considered as an essential element, but it has positive growth effect including increased dry mass and yield, enhanced pollination and most commonly increased disease resistance (Gillman et al., 2003) ${ }^{[2]}$. The role of silicon in plant biology is known to tolerate multiple stresses including biotic and abiotic stresses. It is also known to increase drought tolerance in plants by maintaining plant water balance, photosynthetic activity and erectness of leaves and structure of xylem vessels regulating transpiration rates (Melo et al., 2003) ${ }^{[5]}$.

\section{Material and methods}

The present experiment was conducted at Regional Horticultural Research Station, ASPEE College of Horticulture and Forestry, Navsari Agricultural University, Navsari during 2017-18 and 2018-19. An experiment was laid out in a randomized block design, comprising of three levels of potassium silicate and silicic acid (1,2 and $3 \mathrm{ml} / \mathrm{l} / \mathrm{plant})$ along with control. The treatments were replicated thrice. The effects of foliar applications at $2^{\text {nd }}, 3^{\text {rd }}$ and $4^{\text {th }}$ months after planting of different levels of potassium silicate and silicic acid on yield and yield attributes of banana cv. Grand Nain were recorded.

\section{Results and Discussion}

Foliar application of potassium silicate @ $3 \mathrm{ml} / \mathrm{l} / \mathrm{plant}$ at $2^{\text {nd }}, 3^{\text {rd }}$ and $4^{\text {th }} \mathrm{MAP}\left(\mathrm{T}_{4}\right)$ recorded the maximum number of hands per bunch, weight of bunch, weight of $3^{\text {rd }}$ hand. The same treatment also recorded maximum length and girth of bunch, length of finger from $3^{\text {rd }}$ hand, fingers per bunch and finger weight from $3^{\text {rd }}$ hand. This might be due to the role of silicon which helps in cell division and cell elongation. 
Si improves the structural stability of cell walls during cell elongation and division and thereby maintains cell shape, which may be important for the function and survival of cells (Sivanesan and Park, 2014) ${ }^{[7]}$.

The increased in bunch weight could be the result of an increased in bunch size, finger size and numbers. The increased in finger size can be a major factor contributing to the bunch weight. The increased in finger size might be due to higher photosynthetic activity and biomass production in the plant which might have resulted in more metabolites in the fruits. As the growth and development of the fingers advances, large amount of water and other metabolites moves in to the fingers resulting in higher fruit weight, length and diameter. The increased length, diameter and weight of finger could also be due to the effect of skirting materials. The growth and development of a plant organ follows a rhythm and $\log$ phase contributes maximum to increase in size.

Significantly maximum fruit yield was observed in foliar application of potassium silicate @ $3 \mathrm{ml} / \mathrm{l} /$ plant at $2^{\text {nd }}, 3^{\text {rd }}$ and $4^{\text {th }}$ MAP $\left(\mathrm{T}_{4}\right)$ in banana cv. Grand Nain. Higher yield under silicon sources can be attributed to increased photosynthetic activity of plant, water metabolism, chlorophyll content, more formation of carbohydrates membrane, lipid peroxidation and protective enzymes under drought condition and more uptakes of essential nutrients (Yasuto and Eiichi, 1983) ${ }^{[10]}$.

Another reason for the higher yield might be that the silicon in plants can stimulate nutrient uptake and plant photosynthesis (Smith, 2011). As silicon helps in cell division, may result in production of more number of fruits. Similar observations were made by Gorecki and Busch (2009) [3] in green house cucumber where results revealed that, increased yield was attributed on the number of fruits. Nesreen et al. (2011) ${ }^{[6]}$ noticed that application of silicon increased the number of pods per plant in beans. Stamatakis et al. (2003) ${ }^{[8]}$ reported that, silicon application increased fruit retention and increased number of fruits per plant in tomato.

Increased bunch characters and yield might have attributed to leaf erectness which facilitated better penetration of sunlight leading to higher photosynthetic activity of plant, more formation of carbohydrates and more uptakes of nutrients.

The higher yield might be attributed to the essential role of silicon and counteracting the adverse effects of water stress and disorders on growth and fruiting as well as enhancing the tolerance of the trees to drought, water transport and root development (Epstein, 1999 and Matichenkov et al., 2000) ${ }^{[1,}$ 4].

Table 1: Effect of foliar application of silicon on yield and yield attributes in banana cv. Grand Nain (mean of two years)

\begin{tabular}{|c|c|c|c|c|c|c|c|c|c|c|c|}
\hline Treatments & $\begin{array}{c}\text { Bunch } \\
\text { length } \\
(\mathrm{cm})\end{array}$ & $\begin{array}{c}\begin{array}{c}\text { Bunch } \\
\text { girth } \\
(\mathrm{cm})\end{array} \\
\end{array}$ & $\begin{array}{c}\text { Hands } \\
\text { per } \\
\text { bunch }\end{array}$ & $\begin{array}{c}\text { Fingers } \\
\text { per } \\
\text { bunch } \\
\end{array}$ & $\begin{array}{c}\text { Finger } \\
\text { length } \\
(\mathrm{cm}) \\
\end{array}$ & \begin{tabular}{|c|}
$\begin{array}{c}\text { Finger } \\
\text { girth }\end{array}$ \\
$(\mathrm{cm})$ \\
\end{tabular} & $\begin{array}{c}\text { Fingers } \\
\text { of } 3^{\text {rd }} \\
\text { hand } \\
\end{array}$ & \begin{tabular}{|c|} 
Finger \\
weight from \\
$\mathbf{3}^{\text {rd }}$ hand $(g)$ \\
\end{tabular} & \begin{tabular}{|c|}
$\begin{array}{c}\text { Weight of } \\
3^{\text {rd }} \text { hand } \\
\text { (kg) }\end{array}$ \\
\end{tabular} & \begin{tabular}{|c|}
$\begin{array}{c}\text { Bunch } \\
\text { weight } \\
(\mathrm{kg})\end{array}$ \\
\end{tabular} & \begin{tabular}{|l|} 
Fruit \\
yield \\
$(\mathrm{t} / \mathrm{ha})$ \\
\end{tabular} \\
\hline Control & 70.92 & 87.96 & 7.13 & 151.75 & 17.38 & \begin{tabular}{|l|}
11.75 \\
\end{tabular} & 15.89 & 167.33 & 2.63 & 24.16 & 83.90 \\
\hline $\mathrm{T}_{2}$ Potassium silicate @ 1ml/1/plant & 73.88 & 90.33 & 7.38 & 155.38 & 18.33 & 11.92 & 16.00 & 170.88 & 2.71 & 25.72 & 89.30 \\
\hline \begin{tabular}{|ll}
$T_{3}$ & Potassium silicate @ 2ml/1/plant \\
\end{tabular} & 79.25 & 96.50 & 8.13 & 160.67 & 19.08 & 12.13 & 17.05 & 183.75 & 3.09 & 26.77 & 92.93 \\
\hline \begin{tabular}{|lll}
$T_{4}$ & Potassium silicate @ 3ml/1/plant \\
\end{tabular} & 87.67 & 105.00 & 9.63 & 169.67 & 20.63 & 12.83 & 17.79 & 207.63 & 3.66 & 31.65 & 109.87 \\
\hline Silicic acid @ 1ml/1/plant & 77.25 & 93.67 & 7.63 & 158.13 & 18.50 & 12.13 & 15.93 & 178.04 & 2.81 & 26.00 & 90.27 \\
\hline Silicic acid @ 2ml/1/plant & 81.75 & 99.88 & 8.67 & 164.29 & 19.50 & 12.38 & 17.31 & 194.00 & 3.33 & 28.77 & 99.89 \\
\hline Silicic acid @ 3ml/1/plant & 83.21 & 102.92 & 9.04 & 166.83 & 19.96 & 12.63 & 17.67 & 199.13 & 3.53 & 29.58 & 102.68 \\
\hline S Em \pm & 2.45 & 2.94 & 0.27 & 3.18 & 0.58 & 0.40 & 1.02 & 5.23 & 0.11 & 0.86 & 2.99 \\
\hline CD $0.05 \%$ & 7.07 & 8.49 & 0.79 & 9.19 & 1.69 & NS & NS & 15.11 & 0.31 & 2.49 & 8.65 \\
\hline \multicolumn{12}{|c|}{ Interaction (Year $\times$ Treatments) } \\
\hline $\mathrm{SEm} \pm$ & 3.86 & 4.64 & 0.41 & 5.02 & 0.91 & 0.63 & 1.45 & 8.22 & 0.16 & 1.32 & 4.57 \\
\hline CD $0.05 \%$ & NS & NS & NS & NS & NS & NS & NS & NS & NS & NS & NS \\
\hline CV \% & 8.45 & 8.31 & 8.71 & 5.40 & 8.30 & 8.92 & 14.90 & 7.66 & 9.01 & 8.29 & 8.29 \\
\hline
\end{tabular}

\section{References}

1. Epstein E. Silicon-Annual review on plant physiology. Pl. Mol. Biol 1999;50:641-644.

2. Gillman JH, Zlesak DC, Smith JA. Applications of potassium silicate decrease black spot infection in Rosa hybrida 'Meipelta'. Hort. Sci 2003;38(6):1144-1147.

3. Gorecki RS, Danielski-Busch W. Effect of silicate fertilizers on yielding of greenhouse cucumber (Cucumissativus L.) in container cultivation. J Elementology 2009;14(1):71-78.

4. Matichenkov VV, Calvert DV, Synder GH. Prospective of silicon fertilization for citrus in Florida. Proc. Soil and Crop Sci. Soc., Florida 2000;5:137-141.

5. Melo SP, Korndorfer GH, Korndorfer CM, Lana RM, Santan DG. Silicon accumulation and water deficient tolerance in grasses. Sci. Agricola 2003;60:755-759.

6. Nesreen H Abou-Baker, Abd-Eladl M, Mohsen M Abbas. Use of silicate and different cultivation practices in alleviating salt stress effect on bean plants. Australian J. Basic \& Applied Sci 2011;5(9):769-781.

7. Sivanesan I, Park S. The role of silicon in plant tissue culture, Frontier Plt. Nutri 2014;5:1-5.

8. Stamatakis A, Papadantonakis N, Lydakis-Simantiris N, Kefalas P, Savvas D. Effects of silicon and salinity on fruit yield and quality of tomato grown hydroponically. Acta Horticuturae 2003;609:141-147.

9. Thangaselvabai T, Suresh S, Prem Joshua J, Sudha KR. Banana nutrition. A Review Agric Rev 2009;30:24-31.

10. Yasuto M, Eiichi T. Effect of silicon on the growth of cucumber plant in soil culture. Soil Sci. \& Plant Nutri 1983;29(4):463-471. 